\title{
Ioan Halmaghi and the "Wondrous Craft" of the Păscălie. Bibliomancy and the Calculation Systems of Eastern Chronology at the End of the Eighteenth Century ${ }^{1}$
}

\author{
Valer Simion Cosma \\ Independent researcher
}

\begin{abstract}
Along with $19^{\text {th }}$-century folklore material, church documents from the $18^{\text {th }}$ and $19^{\text {th }}$ centuries emphasize the Păscălia as a book used in bibliomancy. In this study, I aim to explore the originally allowed and designated functions of this writing, and to provide an explanation for why this book was associated with the world of bibliomancy in both folklore and in the officially sanctioned culture of the Uniate clergy from Transylvania. Furthermore, by focusing on the specific case of the Uniate vicar Ioan Halmaghi, who was educated in Roman-Catholic institutions, I set out to explore the attitude of the elite clergy toward this text, and to highlight how a corpus of pre-modern and un-Western knowledge was simply ejected into the sphere of magic and superstition.
\end{abstract}

Keywords: Paschalia, bibliomancy, $18^{\text {th }}$ century, priest, superstition, Enlightenment

The practice of divination using church books has been mentioned by scholars of folklore and popular culture ever since the $19^{\text {th }}$ century, but it has not enjoyed much attention from Romanian researchers until the last two decades. Alexandru Ofrim (2000, 2001), Cristina Gavriluță (2008), or Mircea Păduraru (2014) have produced a series of remarkable works with respect to this practice, highlighting its continuity on all levels of society and the religious fervour created around bibliomancer priests, despite the advance of modernity. The same studies have underlined the role of bibliomancy in diagnosing the charm or malediction that was alleged to have caused someone's illness, or any other type of trouble that could befall an individual, a family, or a community, as well as how this practice connects to the idea of divine justice (GAVRILuță 2008:217-218; OFRIM 2000:285). Likewise, the aforementioned contributions (OFRIM 2000:299-303; PĂDURARU 2014:249-250) have outlined that bibliomancy was placed in the category of practices tolerated by the church hierarchy, despite some periodic condemnations that invoke church canons concerning witchcraft, astrology, and divination.

${ }^{1}$ The research leading to these results has received funding from the European Research Council under the European Union's Seventh Framework Programme (FP7/2007-2013) / ERC grant agreement № 324214 . 
Another category of substantial contributions comes from Hungarian researchers in Romania as well as Hungary, who have particularly studied the way Hungarians and Szeklers resorted to the services of Romanian priests in Transylvania and also how the rituals they conducted fit into the folk magical-religious system. A series of practices such as divinations, exorcisms, maledictions, and miraculous healings performed by Romanian priests have been analysed and discussed, based on ample folkloric material, in works published by Vilmos Keszeg (1996; 2007), Éva Pócs (2004), Tünde Komáromi (2010) and Dóra Czégényi (2014). These works have shed light on the main features attributed to the figure of the Romanian priest in Hungarian folk mythology (CzÉGÉNYI 2014) and aspects of resorting to his services as a healer (KOMÁROMI 2010). In addition, they show that the history of bibliomancy in the modern and contemporary era is not necessarily one of decline, but rather one of continuity and adaptation.

If, nowadays, expressions such as "opening the book", or "opening the Pravila" are used with respect to bibliomancy all over Romania, the first documented uses of this practice in Romanian communities comes from $18^{\text {th }}$ century Transylvania and $19^{\text {th }}$ century folklore collections, indicating a specific terminology. We can better understand bibliomancy and how it relates to the sphere of clergical activity by examining this terminology, and especially by thoroughly studying the Păscălie, a writing from which most of the terms describing this practice derive. For this purpose, in the following pages I set out to succinctly present this terminology, then focusing on the Păscălie, exploring how it relates to divination and the sphere of institutionalized religion as it ensues from church discourse comprised in several documents and ecclesiastic writings from $18^{\text {th }}$ century Transylvania. I will particularly focus on several documents from the final decades of the $18^{\text {th }}$ century, belonging to Ioan Halmaghi, the Uniate vicar of Făgăraș. By shedding light on his attitude toward the Păscălie, I aim to illustrate that for the generation formed in the spirit of the Enlightenment and Catholic reformism essential aspects of the knowledge tradition specific to the Eastern Christianity were reduced to magic and superstitions.

\section{PĂSCĂLIE, PĂSCĂLIER, PĂSCĂLIT}

The first document that attests to this form of divination discusses "looking in the Păscălie", as it comes across from a patent ${ }^{2}$ emitted on the $9^{\text {th }}$ of October 1787 by count Kristofor Nicky, president of the Magyar Lieutenancy Council:

"For those who look in the păscălie or go about in the country with similar books (...) His Imperial Majesty have noticed how numerous Greek-Uniate priests and readers, thus go around the country and among the people, and in various ways, as though they would sell holy things and books, extort money (...) so that these wicked deeds should be sternly punished. To Your Holiness with a Most High Name it is commanded that vigorously and studiously you should

\footnotetext{
${ }^{2}$ Throughout the $18^{\text {th }}$ century, imperial authorities emitted a series of royal patents, which aimed to restrict the peddling of religious and liturgical books published in Moldavia and Wallachia, in order to protect the newly-founded Uniate Church. The series is opened by the imperial orders emitted by the Empress Maria Theresa in November 1746 and June 1747, respectively (BunEA, 1902:357).
} 
survey those priests so that such deeds, the extortion and unlawful circulation of money should in no way be allowed" (DuDAș 1974-1975:156).

The reference to the Păscălie and the formulae derived from the title of this writing are also encountered in other source documents, such as church documents and writings, folk tales ${ }^{3}$, folklore materials in the press or in folklore collections ${ }^{4}$ as well as literature. ${ }^{5}$ For instance, in a collection of homilies from 1811, the Uniate clergyman Petru Maior berates a series of customs, practices and folk beliefs in a style specific to the discourse of Catholic reformism with Enlightenment undertones.

"All those who believe in păscălii, chants, spells, all lose their souls; but how could you believe, you, an old hag, hardened in evil doings, wrinkled, thin, powerless, hunched, crippled, a corpse, that with two or three words, with three or four yawns, you could lengthen the years of your life? God alone ends life or adds years to it, (...) and how can you believe a scholar and cunning Pharisee who reads lies in the păscălie and tells your fortune like gypsies (...)?"

(Bogdan-DuiCă 1893:23)

The fragment places the păscălies in the category of illicit magical practices and literature, leading to the loss of one's soul, and the ones who engage in this type of divination are described as liars and Pharisees. The clergyman's discourse describes the Păscălia as a mendacious book, or one liable to mendacious readings/interpretations.

We learn more on the terminology used by Transylvanian Romanians with respect to divination by means of church books from the dictionaries, lexicons, and encyclopaedias

\footnotetext{
${ }^{3}$ The Păscălier, as an example of charlatanry or just good fortune, is a character often encountered in folk tales, such as "The Păscălier Gipsy" or "The Blândoc," comprised in the tome Folk Tales, published by Ioan Pop Reteganul in Sibiu, in 1895. The priest as "Păscălier" is encountered in the folk tale "Preotul cu Păscălia" - "The Priest with the Păscălia," published under the Anecdotes section in three consecutive issues (2-4) of the Rândunica (The Swallow) magazine in the year 1894.

${ }^{4}$ In issue No. 6 of the Familia magazine, published in Oradea in 1883, we encounter a memoirist text entitled "Negrea Păscălitorul" - "Negrea the Păscălitor," by Grigore Sima a lui Ion (61-64): "C-am cătat în păscălie/ Și mi-o dă maică-sa mie!" - "For I looked up in the păscăli/ And "mum gives it to me!" is a verse in witty a folkloric witty chant comprised in the tome Doine și strigături din Ardeal - Doinas and Witty Chants from Transylvania, published in Braşov in 1895 by Ion Urban Janik and Andreiu Bârseanu (79); Visiting astrologers and păscălitors are mentioned in a writing with the title Superstițiuni păgubitoare ale poporului nostru. Descântecul și leacurile băbești, duhurile necurate, vrăji și farmece, sărbători fără de rost-Our People’s Damaging Superstitions. Chants and Old Wives'Remedies, Unclean Spirits, Spells and Charms, Pointless Holidays, which was meant to combat superstitions and was published by the writer George Coşbuc in 1909 in Bucharest (89); In the volume Comorile - The Treasures from the opus Mitologie Românească-Romanian Mythology, published in Bucharest in 1915, the folklorist Tudor Pamfile mentions the practice of looking in the Păscălie performed by those searching for hidden treasures (PAMFILE 1915:53).

${ }^{5}$ The păscălier as charlatan appears in the folklore-inspired parodic poem "Pipăruș-Viteaz", published by the writer George Coșbuc in the Tribuna - The Tribune magazine in 1889; In issue no. 18 of the Luceafărul - The Morning Star magazine from 1909, Ion Agârbiceanu, Uniate Archbishop and significant prose writer for Romanian literature in the first decades of the $20^{\text {th }}$ century, publishes the short story "Părintele Vartolomei Bogdan" - "Father Vartolomei Bogdan", about a priest who had a reputation for divining in the Păscălie (409-413). The same subject is also approached in a far more extended novella entitled "Păscălierul" - "The Păscălier", the first version of which appeared in the tome Short Stories, published in Sibiu in 1920.
} 
published in the $19^{\text {th }}$ century, which index terms such as "a păscăli", "păscălit", "păscălire", or "păscălitură". For example, in Lesicon românescu-latinescu-ungurescu-nemțescu Romanian-Latin-Hungarian-German Lexicon, the first Romanian dictionary, published in Buda in 1825, we find Păscălire as "subst. praedictio, divinatio; jövendölés, jövendö mondás; Weissagung, Wahrsagung," and Păscălitură as "subst. vaticinium, oraculum, divinatio; jövendölés; die Weissagung, Wahrsagung" (II, 486). Dictionariulu Limbei Romane - The Dictionary of the Romanian Language, published in Bucharest by August Treboniu Laurian and J.C. Massimu in 1876, contains the same entries that describe Pascalire as "divinări, vaticinari; a spune pascalia cuiva, a divina, a predice" [divinations, vaticinations; to tell someone their pascalia, to divine, to foretell], and Pascalitura as "vaticinium, divinatio, oraculum; actione si effectu de pascalire" [vaticinium, divinatio, oraculum; the action and the effect of pascalire] (595-596). Later on, in Dicționarul Enciclopedic Ilustrat "Cartea Românească" - The Encyclopaedic Illustrated Dictionary "The Romanian Book," published by the folklorist I.A. Candrea in 1931, we find the verb a păscăli, which means "to tell one's fortune with the păscălie" (907).

Those who engage in such practices are called păscălier, păscălitor, păscălău, or păscălar (BăLTEANU 2001:116-117). For instance, the 1825 Lexicon records the term Păscălitoriu, "subst. Vates, divinus, fatidicus, vaticinator, vaticinus; jövendölö, jövendö, mondó; der Waisssager" (486), and the Illustrated Dictionary published by I.A. Candrea glosses the term Păscălitor, "cel ce păscălește, cel ce știe să caute în zodiac, ghicitor" [he who reads the păscălie, he who knows how to read a Zodiac, soothsayer] (1931:907).

The same dictionaries and other works published in the same period also provide us with information on Păscălie or paschalia, "liber vaticinus: jövendölö könyv; ein weissagerisches Buch" (LESICON 1825:486), or "1. calendariu perpetuu, calendariu in care se indica epoca pasceloru si celloru alte serbatori pre mai multi ani; 2 . Carte de divinatione, de predictione; in genere, veri-ce mediu de divinatione; a cauta in pascalia, a spune cuiva sortea dupo pascalia; - prov.[erbul] a si perde pascalia $=$ a i se incurca liciele, a face errori de calculu, a se insella." [1. Perpetual calendar, a calendar which indicates the time for Pascha and all the other holidays for several years at a time; 2 . Divination, predictions book; in general, whichever means of divination; to look in the pascalia, to tell someone's fate according to the pascalia; - the proverb to lose one's pascalia $=$ to mix one's threads, to make calculation errors, to be deceived] (LAURIAN, MASsimu 1876:595). ${ }^{6}$ What ensues from these definitions is that the Păscălie has two accepted meanings. On the one hand, its main one, as divinatory text, and on the other hand, as a calendar. In his book on the imaginary dimension of books in traditional

\footnotetext{
${ }^{6}$ We also find similar definitions in ȘĂINEANU 1896:467: "1. Calendar perpetuu cu indicațiuni astrologice (după cari se poate hotărî data sărbătorii Paştilor pentru orice an); 2. Carte de ghicit norocul fiecăruia; 3. fig. A-și pierde pascaliile, a face erorỉ de calcul (cf. a-și pierde călindarul). [Gr. mod. Pashalia, Paști]" - "1. Perpetual calendar with astrological indications (according to which the date for celebrating Pascha can be decided for every year); 2. A book for divining every person's fortune; 3. fig. To lose one's pascalii, to make calculation errors (cf. to lose one's calendar)," or DiACONOVICH 1904:536: "carte ce cuprinde indicațiuni astrologice, după cari se poate hotări data serbătorilor Pascilor pentru ori ce an. Se mai numesce P.[ăscălie] cartea din care se poate predice viitorul" - "a book which comprises astrological indications, according to which one can decide the date for the Pascha holiday for every year. Also called P.[ăscălie] is the book from which the future may be foretold."
} 
Romanian culture, Alexandru Ofrim writes that the Păscălie was originally a table used to calculate the date for Easter [Pascha], as well as an instrument for measuring time, incorporated into calendars (OFRIM 2001:283) or other religious and liturgical books ${ }^{7}-$ especially the Psaltirion and the Ceaslovs [Books of Hours] (Docan 1910:356) - printed by the church throughout the $18^{\text {th }}$ and $19^{\text {th }}$ centuries.

Next, I set out to explore the uses and functions of the Păscălie in depth by analysing some documents from the end of the $18^{\text {th }}$ century, which belong to a Transylvanian Uniate Vicar. As we can notice from the previously referenced $18^{\text {th }}$ and $19^{\text {th }}$ century documentary sources, and as we can also observe from their content, when discussing the Păscălie and its many uses and meanings, we should be mindful of two fundamental aspects:

1. On the one hand, we should keep in mind that the Uniate Church's hierarchy ${ }^{8}$ took upon itself a mission to reform popular piety and to enlighten the minds of the faithful, especially during the second half of the $18^{\text {th }}$ century (MIRON 2004; DUMITRAN 2007). The fact that the Uniate Church entered a trajectory of religious reformism, confessionalization ${ }^{9}$, and social disciplining ${ }^{10}$ profoundly influenced its attitude, not only toward the magical-religious beliefs and practices of the Eastern population that had recently been integrated into the sphere of Catholicism, but also toward science/ knowledge in its pre-modern understanding.

2. On the other hand, we should be mindful of the category of calendars and various divinatory and astrological writings, all of which comprised the Păscălie and circulated as corpuses that encompassed a mixture of information on Zodiac signs, meteorological prediction methods, prayers, psalms, magical chants, and techniques for interpreting signs. These types of printed texts expanded continuously throughout

\footnotetext{
${ }^{7}$ The tomes entitled Bibliografia Românească Veche - Old Romanian Bibliography, published by Ioan Bianu and Iosif Hodoș at the beginning of the $20^{\text {th }}$ century, index numerous religious and liturgical book titles, which also comprise the Păscălie. Along the same lines, I would also like to mention editions of the Catavasier, Bucharest 1724, Râmnic 1747, Blaj 1793; Psaltirion, Bucharest 1756; Orologhion, Blaj 1766; Acathist, Sibiu 1801; Polustav, Buda 1807, Small Octoih, Sibiu 1808, Psaltirion, Sibiu 1912, Calendar, Sibiu 1816 etc. (BIANu, Hodoş III 1910:22, 97, 136, 429, 503; BiAnU, Hodoș IV 1944:135, 146, 267, 283).

${ }^{8}$ This mission to reform popular piety, and to socially discipline clergymen and faithful lay people would also become central in the activity of Orthodox hierarchs, especially throughout the $19^{\text {th }}$ century. Numerous works on church history highlight this aspect, and I will especially mention here the monographic writings dedicted to the activity of hierarchs such as Bishop Vasile Moga (STANCA 1938) or Metropolitan Andrei Șaguna (PoPEA 1879; LuPAŞ 1921), but also general church history works, such as the classical History of the Romanian Church and of the Romanians' Religious Life, in 2 volumes, by Nicolae Iorga (1908), or Istoria bisericească a românilor ardeleni - The Church History of Transylvanian Romanians, by Ioan Lupaș (1918).

${ }^{9}$ The concept of confessionalization has been developed by Heinz Schilling in articles such as "Die Konfessionalisierung im Reich: Religiöser und gesellschaftlicher Wandel in Deutschland zwischen 1555 und 1620", in Historische Zeitschrift 246 (1988):1-45, and Wolfgang Reinhardt, "Zwang zur Konfessionalisierung? Prolegomena zu einer Theorie des konfessionallen Zeitalterst", in Zeitschrift für historische Forschung 13, (1983): 257-277. For a detailed discussion of this topic, including critical remarks on this concept, see Central European History, Volume 33, No. 1 (200): "Priests and Pastors in Central Europe 1500-1700".

${ }^{10}$ For the concept of social discipline see Gerhard Oestreich, "The Structure of the Absolutist State" in Neostoicism and the Early Modern State (1982) and Amy Nelson Burnett, "Basel's Rural Pastors as Mediators of Confessional and Social Discipline" in Central European History, Volume 33, No. 1 (200):67-85.
} 
the $18^{\text {th }}$ and $19^{\text {th }}$ centuries, as they were usually published under the patronage of churches and mainly distributed among church servants (GASTER 1883; CARTOJAN 1980), who were the main category of alphabetized people up until the second half of the $19^{\text {th }}$ century (MARICA I 1977:90). At the same time, we should also be aware of this aspect because of their role in influencing and perpetuating a pre-modern vision of the world and the functioning of the Cosmos (OFRIM 2004), in tight connection with theological literature (JigA-ILIESCU 2005).

\section{IOAN HALMAGHI AND THE PĂSCĂLIE}

Ioan Halmaghi belongs to the first generations of Uniate hierarchs and clergymen from the second half of the $18^{\text {th }}$ century, who studied theology in Blaj and Vienna. In the imperial capital, he studied at Santa Barbara College together with Samuil Vulcan, future bishop for Oradea, Ioan Para, future vicar of Năsăud, and for a period of Făgăraș, Iosif Meheși, clerk at the Aulic Chancellery of Transylvania, and Ioan Cornelli, future vicar for the Diocese of Oradia (DuICU 1986:112-113). In 1783, Ioan Halmaghi taught German at the Blaj Gymnasium, then served as parish priest and dean, and starting with 1786, vicar of Făgăraș. Between 1796 and 1803, he was also the vicar of Rodna, after which he was removed under the accusation of being "corrupted in the mind." He spent several years at the Monastery in Blaj, and after the accusation proved unfounded, he was reinstalled as vicar of Făgăraș from 1807 to 1815 (DUMITRAN 2007:302, METEŞ 1929:458). The historian Nicolae Iorga mentions Halmaghi as author of a work called Invățătură pentru proști - A Teaching for Fools (IoRGA 2012:215).

Halmaghi's involvement in the campaign to illuminate the faithful flock and combat superstitions, which was conducted by the Uniate Church in tandem with imperial authorities, also comes across from a letter written in February 1789 and addressed to an imperial commissary. It was composed in Latin and recently published in a Hungarian translation in the tome Felvilágosodás és babonaság. Erdélyi néphiedelemgyüjtés 1789-90-ben, published by Ambrus Miskolczy. The letter comprises a report that had been elaborated based on an order to "observe and recount the superstitions and preconceptions dominant among the common folk, which harm the purity of doctrines and religious practices" (HALMAGHI 2016:188). After he notes "with sadness that the majority of these superstitions still flourish, although some of them have waned, while others have begun to spread", the vicar records all manifestation of superstitions that he was aware of, grouping them in three basic categories:

1. Divination/soothsaying - quidem Classem ea omnia quae sub generali Nomine divinationis venire possunt, in

2. Magical Chants - quae quoquo modo artificiosam incantationem exprimere videntur, in

3. Witchcraft, Magic, Satanism - demum, quae spectant ad magicas, sive satanicas artes, ut in specie etiam maleficium referenda censui (188).

Among the most widespread practices is divination based on a Romanian manuscript called the Păscălie - sic dicta Paskalia - which "contains an illustration, a circle divided in 99 segments numbered continuously (1-99), each segment corresponds to a life event described by a chant in the text". Regarding the divinatory technique, he mentions that 
"one lets a grain of wheat fall on the middle of the circle and marks the number of the slice on which it has stopped, and the chant with the respective number from the text then indicates the future events in the life of the respective person" (188). The text authored by the vicar also highlights that the Păscălie is a divinatory text, which is also underlined in the homily fragment later published by his colleague, Petru Maior, and presented in the previous pages.

After he emphasizes that this practice requires the capacity to read, an aspect which indicates that these soothsayers were literate, he also mentions that "many times, the village priest himself practices this sinful craft", and as a conclusion with respect to the situation of the church in the area, he says that he has never encountered "even a single priest who has not engaged in such practices, and consequently, cleansing the parishes would be very difficult, and this phenomenon can only be countered by creating a staterun education system in the area, which would impede upon the transmitting of such superstitions and occult practices to new generations" $(188,197)$.

The report also describes other forms of divination, such as fortune telling by using beans or peas, also practised by some women who were looking to earn money, or fortune telling using birds. He mentions the use of certain church or hallowed objects in various magical practices as well as other details concerning the forms of magic widespread throughout the peasant world. In the case of bibliomancy, along divination by means of the Păscălie, Halmaghi also speaks of a version that requires use of the Bible. On this type of divination, he mentions that it is practiced by priests, particularly on the occasion of performing the last rites for sick people. It functions by randomly opening the book and telling the ensuing fortune of the sick person based on the chapter where the Bible had been opened. ${ }^{11}$ Also in this category, he mentions divination based on a manuscript similar to the Păscălie, in which prediction relies on the careful observation of the changes in certain areas of the respective person's body (189-200). Halmaghi was probably referring to the Trepetnic. About the Trepetnic (from the Slavonic word designating a tremor), whose dissemination in the Transylvanian space is widely attested beginning in the $17^{\text {th }}$ century by researchers who studied popular literature and the circulation of the book, Nicolae Cartojan says that it is a book "that foretells a person's future according to the various movements of the body, such as: the beating of the eyes, the batting of the lashes, the beating of the palms, the smacking of the lips etc" (CARTOJAN II 1974:227).

\footnotetext{
11 The habit of using the Bible in divination practiced at a person's dying bed is also mentioned in the work Funeral for Romanians. An Ethnographic Study by the priest-folklorist Simion Florea Marian, first published in 1892. He describes it as taking place after the Holy Unction, when the priest opens the Bible in order to read from the Gospel, and if "it happens that the beginning of the Gospel, which was read to them at the end, should only be printed with black letters. On the contrary, the person who stays awake throughout the Unction will not not suddenly get well upon its completion, but rather slowly, and also those for whom the beginning of the Gospel that was read to them at the end is printed with red letters will get well and rise as soon as possible from their bed of sorrow" (MARIAN 2008:20).
} 


\title{
THE HAND OF DAMASKIN AND THE CALCULATION OF CALENDAR IN THE EASTERN TRADITION
}

In the tomes that comprise The Catalogue of Romanian Manuscripts, Gabriel Ștrempel inventories a series of miscellanea that also includes the Păscălie, along with liturgical texts and astrological or divinatory writings, most of which were printed by the church (I-IV 1978-1992). By studying these fragments, we notice that the Păscălie is a table that establishes the date for celebrating Easter (Pascha) and other correlated holidays for a longer period of time. This list represents the fundament for the Eastern Church calendar, and relies on very specific calculation methods. One of the most widely used such methods, which lies at the basis of the various Păscălii, is depicted in a writing called Mâna lui Damaskin - The Hand of Damaskin. An edition of this writing was published in Sibiu in 1793 by the same Ioan Halmaghi, four years after the report presented above. ${ }^{12}$ The fact that the vicar was interested in the question of the Păscălie and studied it in depth ensues from the very foreword of this edition, written by Halmaghi himself.

\begin{abstract}
"Since I understood how much use the hand of Damaschin comprises for the workings of our Church of the East, I yearned to seize its teaching and meaning, as a stag yearns to reach a spring. Therefore, in time, after I had deliberately sought to learn about it, some writings fell into my hand, which very briefly uncovered this craft; I, therefore, committed my strain, I released myself toward its meaning with the help of God, I also searched in the books of the Holy Church, and after some wear, I finally grasped the meaning of the hand of Damaschin, with its teaching and meaning, and I was thus more thoroughly assured of its priceless use.

By learning this craft, either at home, or on the road, or wherever you might be, you can set yourself right and be sure to know about the ordinances of our Church by heart and without a book, rather than some other one using a book; that all pashaliia, which is found in the books of hours, in psalteries, or in other Church books, is composed according to the hand of Damaschin, for which cause the teachers of pashalia and the typographers, if they not be inured to this craft, may delude their minds, and some have already deluded themselves with respect to the setting of the Church ordinances over the years, as they are also, just as other people, surrounded with the weakness of human mettle...

This skillful craft is called the hand of Damaschin, because its entire craft is shown on the hand, and the entire key of the pashalia is calculated on the hand by heart, and it is, as I have seized it, invented with great craft by the most holy Kir Damaschin, Bishop of Râmnic, and its understanding is easy for the studious ones" (BIANU, Hodoş II 1910:355).
\end{abstract}

The foreword written by the vicar argues that the manuscript called Păscălie and used by priests in certain divinatory practices originally served a different function than that of an instrument for divination, and that it was fundamental for the Eastern liturgical life and the church calendar. By comparing how he had dismissively defined

\footnotetext{
${ }^{12}$ The Library of the Romanian Academy in Bucharest holds a copy of this edition, as we learn from the work on old Romanian bibliography signed by Bianu and Hodoș (1910), which renders a fragment from the foreword written by Vicar Ioan Halmaghi.
} 
the Păscălie as a divinatory manuscript in the report he had previously presented, with the fragment in which he justifies his interest for the craft comprised in this writing, it becomes evident that at the time he became vicar, the cleric, with his education in Roman-Catholic learning institutions, did not have a profound knowledge of these fundamental issues from the tradition of the Eastern Church. This illustrates both the fault between the two churches, as well as the fault between his generation of church hierarchs and their subordinate clergy, on the one hand, and the communities that they shepherded, on the other hand.

Besides the authorship of this calculation system, attributed to Damaschin, bishop of Râmnic, Buzău, and Severinul Nou (1703-1726), ${ }^{13}$ Ioan Halmaghi underlines the use of this craft and mentions that the prefaced edition comprises "for the first time in a selfstanding work, the rules for the computation system generally known as «The Hand of Damaschin»." Thereafter, he succinctly explains the role of the hand in this calculation method and the surprising effect that its practice generates on people. "According to this system, the chronology elements, namely the orbit of the Sun and the Moon, the hand of the year, the foundation and the others, such as also the letter of the Pascalie, etc. are calculated on the finger joints, and older people could not be amazed enough at the wonderful craft that had concocted a relation between the calendar and the finger joints, and which allowed for the calculation of each year's holidays on the hand of every mortal" (DocAN 1910:358).

The Uniate hierarch explores the Eastern tradition, and underneath the layer of divinatory practices widespread among his subordinate clergy, he discovers a different type and corpus of knowledge, which he strives to understand and bring to the surface. We are talking about an effort to organize knowledge, by publishing in a distinct text, without adding or combining other types of texts, the compute rule called "The Hand of Damaschin", which lies as the foundation for elaborating the Păscălii. Usually, as Nicolae Docan attests, the different calculation systems and their rules were comprised in writings that accompanied the Păscălii included in Church books. Such an example is Rojdialnița ce afli naștirea lunii în toate lunile, pre 19 ani or Selinodromion, written by Mitrofan, the hieromonk from the Bisericani Monastery, and comprised in the SlavonicRomanian Psaltery printed by Metropolitan Dosoftei in 1680 in Iași. The Psaltery printed in Sibiu in 1805 also comprises, as an annex to the catalogue of years, rules for calculating the various elements specific to the Eastern chronology, and also a table with the phases of the moon (Docan 1910:359). On the importance of this type of craft for the lay and ecclesiastic Orthodox world, we learn more information from the study already cited by the historian Nicolae Docan, which contains an ample discussion about the calculation systems specific to the Eastern chronology and used by the learned scribes of lordly

\footnotetext{
${ }^{13}$ In the cited study, N. Docan shows that the preface signed by the vicar Ioan Halmaghi wrongly attributed the authorship of the calculation method known as The Hand of Damaschin to the bishop of Râmnic, Buzău, and Noul Severin (1703-1726), Kir Damaskin. According to the author, the fact that Dosoftei's Psaltery, printed in Iași in 1680, already contains a Pascalie based on the same rules for calculation, is enough of an argument to hypothesize on a Russian origin for this practice, which may have made its way into Romanian Orthodoxy through Moldavia.
} 
chancelleries from Romanian principalities up to at least the middle of the $16^{\text {th }}$ century. ${ }^{14}$ The same study highlights that the Romanian Orthodox world constantly printed writings that expounded on these calculation methods and contained directions for their use.

Another self-standing edition was published in the form of a brochure in Iași in 1842, entitled Pascalion prințipal, cu titlul Mâna lui Damaschin, composit de Vasile Gavrielovici Lupea, Transilvano-Chiciudian. This one "is structured on questions and answers and written in a popular style, [and is accompanied by] a board that depicts the hand of Damaschin and the relation between the various cycles" (DocAN 1910:359-360). The fact that this edition is written in a popular, more widely accessible style, and according to the model of catechisms, emphasizes the opening to a wider reading audience. As one may notice in Figure 1, the board contains a circle similar to the one described by Halmaghi in his presentation of the divinatory technique from the document presented above. As in other types of bibliomancy, ${ }^{15}$ which require using church books in a manner different from the one prescribed by liturgical literature and church canons, the divination in the Păscălie as described by vicar Halmaghi seems to involve using the illustration required in the calculation system as support for drawing or casting lots.

Returning to the calculation technique called The Hand of Damaschin, the preface from a copy ${ }^{16}$ printed in Iași in 1830 attributes its authorship to Saint Damaschin

\footnotetext{
${ }^{14}$ In Eastern chronology, the starting year is calculated from the creation of the world and not from the birth of Christ, as is the case in the West. There are also significant differences in the methods of calculation, or the starting points for calculation. For instance, "the orbit of the Sun and the orbit of the Moon are also in Western chronology two cycles of 28 days and 19 years, respectively, but with different starting points, namely starting from a different year (...) according to some Western computators, the cycle of the Moon and the golden number were two identical notions, whereas in Wallachian chronology they are two distinct elements." (Docan 1910:355). The underlined differences refer to the calculation rules used in the Western chronology before the introduction of the 'new style' in 1582. These calculations have an essentially religious function, as they were necessary to determine Easter (Pascha) and other holidays that did not have a fixed date.

${ }^{15}$ To this end, I would also like to mention the practice of divination with a judicial character, by using a key and the Psaltery, as described in Învățătură firească spre surparea superstiției norodului [A Natural Teaching Onto the Errosion of the Superstition of the Common Folk], printed in Buda between 18041808: "Besides throwing a sieve, there is also another form of fortune telling that (...) seeks the truth by a key, once again, inherited from the parents. (...) the crazed fortune teller sticks the inherited key into the Bible, at the same place where the Gospel of Saint John begins and in such a way that the main bundle of keys should be left outside of the Bible. Then, he takes a small strap or string, which, according to his fancy, must also be inherited, and with this strap, he ties up the Bible such that the key cannot fall off from it. So, just as with the throwing of the sieve, two persons place their middle fingers under the key's bundle, and lift the Bible into the air. Afterwards, the magister says some uncouth and unintelligible words, and names several persons. When he names innocent persons, the key is not supposed to move, and when he names guilty persons, the key is supposed to spin as hard as possible. Superstitious folk, when they work like this, say that by this manner of fortune telling, the easier one may find out evil doers, the truer it is that the word of God is not deceitful." (STINCAI 1964:89). The same practice is later described in the memorialist writing "Negrea Păscălitorul" - "Negrea the Păscălitor" (1883), by Grigore Sima a lui Ion, and in the article "Credinți populare în cărți bisericești" - "Folk Beliefs in Church Books", published in 1904 in the journal Șezătoarea by the folklorist Grigore Teodorescu-Kirileanu. As one may notice from the fragment at hand, this is the case of a method similar to the one described by Keith Thomas with respect to pre-modern England (1973:255).

${ }^{16}$ That copy is preserved at the Central Universitary Library in Cluj, http://dspace.bcucluj.ro/ handle/123456789/67716.
} 


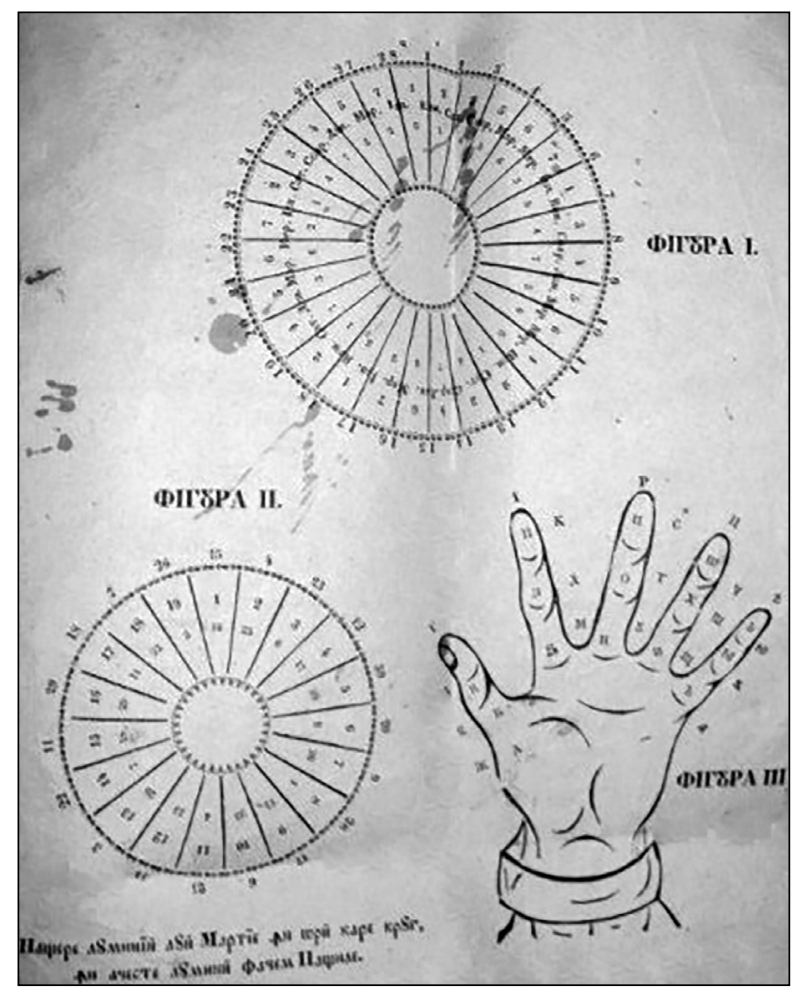

Figure 1. Detail of the Pascalion titled Mâna lui Damaschin ('The Hand of Damaschin'). (Iaşi, 1842; written by Vasile Gavrielovici Lupea)
(John of Damascus), to whom God, through the gift of the Holy Spirit, had uncovered the calculation and the setting of the Pascalia on the hand, and for that reason the calendar is called on the Hand of Saint John of Damascus. That respective copy begins with the rules about the Hand of Damaschin and continues with their calculations and explanations for the fingers of each hand. In order to discover what time Easter (Pascha) would be celebrated on a given year, we must know the temelion and the hand corresponding to that respective year. The temelion runs on the front of the left hand, on the tips and joints of the fingers, while the hand of the year goes on the front and the back of the four fingers on the left hand, beginning with the front of the little finger. The preface also explains what calculations are conducted for the discovery of the temelion

and the hand of the year, and the copy ends with a table that helps calculate the future date of Easter (Pascha). All these techniques are set and calculated only on the left hand, which is why this is called the calculation of the calendar according to the Hand of Saint Damaschin (1830).

The follies mentioned by the vicar and the elders' amazement toward the "wondrous craft" that made a connection between the hands and the calendar reflects the different way in which this calculation technique was perceived outside the restricted circle of those accustomed to the craft. It also suggests an explanation for why the Păscălie was integrated in the wider category of divinatory and astrological literature that circulated in the rural world, especially with the help of priests, ever since the first prints came out of Transylvanian typographies around the middle of the $17^{\text {th }}$ century. ${ }^{17}$ First of all, the very

\footnotetext{
${ }^{17}$ In the first volume of his work on folk literature, widespread among Romanians, Nicolae Cartojan states that "the first book issued from the typography installed in Alba Iulia in 1639 [by the Calvin Prince of Transylvania, Gh. Rákóczi] comprises, along with other texts, a Gromovnic", on which he mentions that "it is an astrology book that expounds on the transformations that will be accomplished on Earth and in the ensuing fate of mankind, according to the zodiac in which doth fall the thunder (...) Gromovnic (from the Slavonic thunder)" (II, 1974:224-225).
} 
act of using this method may be regarded as being part of the same category as the magic or divinatory actions. The Eastern Church discourse on the Păscălie places it under the category of a sacred science, inspired by God, and it explicitly references the future - the calculation for the dates of holidays and for the phases of the moon for a longer period of time - which constitutes the basis for the church calendar that would set the rhythm and structure for the life of communities. Considering that the Păscălie served the main purpose of structuring the calendar in the longer term, in firm connection with the cosmic order, and for the use of the church's ordinance, but also for the use of various quasiillicit forms of prospecting the future, it becomes easy to understand how terms such as "a păscăli", or "păscălitură" developed as synonyms for "fortune telling". Likewise, the term "păscălier", (and its derivatives) grew to be used as generic titles for bibliomancers. As Faith Wigzell showed in her work on divination in Russia during the same historic period, for the pre-modern peasant world, "divination, various in character and function, played an all-encompassing role in daily life as a means of grasping the significance of events and phenomena and offering glimpses into future. At the same time it performed important social functions" (WIGZELL 1998:46). For a peasant society that devotes such attention to calendar and cosmic order, all those methods and writings were sophisticated means of understanding and deciphering how the world works, accesibile to a literate minority.

The fragments presented, correlated with the information on the precarious instruction level of Romanian clergymen from the $18^{\text {th }}$ century, as was emphasized in numerous historical studies, ${ }^{18}$ advance the idea that, for the greatest number of priests, one cannot speak about a very clear delineation between the scientific function - calculation technique - and this writing's function as an instrument of divination, despite numerous church canons that condemned divination as it was considered devilish magic (PoPCuRŞEU). The probable reason for this is that these canons do not specifically refer to bibliomancy (PĂDURARU 2014:250), and in the Eastern Christianity the tradition of OldTestament prophecy, enriched with the Patristic figures of certain clairvoyants from the monastic world, was preserved very well, in tight conjunction with the healer and divine justice mediator roles ascribed to priests.

Throughout this article, I have mentioned several times the connection between the Păscălie and the astrological and divinatory literature comprised in popular calendars, or in other types of writings. The first book printed in the church typography from Alba Iulia in 1639 reveals how the Eastern tradition integrated and perpetuated divinatory and astrological literature up until the late $19^{\text {th }}$ century. Known as Paraclisul Precistei - Precista's Oratory, from Govora (1639), and because the first text it comprised is that respective oratory, this book also contains the following texts:

\footnotetext{
${ }^{18}$ I would particularly like to mention the fundamental work by historian Nicolae Iorga, Sate și preoți din Ardeal - Villages and Priests from Transylvania, published in its first edition in 1902. Likewise, the work Preotimea românească in secolul al XVIII-lea - Romanian Prieshood in the $18^{\text {th }}$ century (1915) by Dumitru Furtună offers numerous details in this respect. The historian Toader Nicoară also brings a contribution to the domain with his work Transilvania la inceputurile timpurilor moderne (1680-1800). Societate rurală și mentalități colective [Transylvania at the Beginning of Modern Times (1680-1800). Rural Society and Collective Mentalities] (1997).
} 
"Molitvas when you awaken from sleep in the morning; Molitvas when you want to go to bed at night; Ten commandments of the Old Law; Two commandments of the Law upon which all the law and the Prophets rely. There are three things that are worthy of blessing, with which God is magnified among men; Four things good for the Annunciation; Seven Sacraments there are of the New Law; Seven gifts there are of the Holy Spirit; Nine fruit of the spirit of the generous person within which the Holy Spirit is begotten; Seven sins are heavier; Seven works there are of mercy; Three things are good about doing good; Three forms of holiness there are that belong to God; Justice according to nature; Justice according to the law; Five natures there are of the body; Four are the final things; Gromovnic; Here you should know over the year how many weeks there are from one big holiday to the next; We see this thing that great temptations and banes befell the Holy Prophet and King David; Sinaxar fragment; Păscălie fragment; The Trepetnic of human signs" (Bianu, SimionesCu 1944:20-21).

Alongside molitvas (prayers), psalms, catechetic and canonical texts, the book further comprises the Păscălie, the Gromovnic, and the Trepetnic, in a juxtaposition that seems to suggest how, despite the repeated condemnations of divination, astrology, and magic, these writings can rather be categorized as scientific, in the pre-modern sense, in that science was accepted/tolerated and perpetuated by the Orthodox Church, especially by way of monks and learned priests. This aspect has been discussed in an article on the presence of zodiacs and of zodiac signs in traditional Romanian culture, written by Laura Jiga-Iliescu, who underlined the fact that

“(...) the Church did not reject the Zodiac per se, but (only) using it as an instrument for divinatory and mantic purposes. The integration of the Zodiac in the official ecclesiastical discourse abided by different reasons than those of predicting and foretelling the future (...) This explains the presence of zodiac signs, of the Moon and the Sun in the structure of the Mineu painted on the inner walls of churches and monasteries, signs learned by the listeners of hagiographies, who were also the onlookers of their illustrations" (2005:25-26).

This knowledge mixes fundamental Christian references with vulgar versions of ancient knowledge on the Cosmos and its working. At least in the case of the clergymen familiarized with this type of literature and accustomed to handling the Păscălie, both for a divinatory purpose and also in order to draw up the calendar, it seems appropriate to set them in the descent of a Byzantine tradition of certain scholars, such as Michael Psellos (1018-1070), who integrated in their cultural horizon both theological knowledge and fundamental doctrines as well as pre-Christian knowledge. From the perspective of scholars such as Psellos, this type of knowledge, drawing its roots in ancient philosophy and occult sciences, "was fundamentally separate from the popular magic peddled by crazy old women and shifty charlatans (...) The occult sciences represented an erudite and exclusive body of wisdom that carried the authority of an ancient textual tradition inherited from the Greco-Roman and Near Eastern worlds" (WALKER 2015:223).

If use of the printing press led to bibliomancy becoming an ever more popular and accessible practice for Transylvanian Romanians due to the widespread Church and astrological literature in the $17^{\text {th }}$ and $18^{\text {th }}$ centuries, the Church documents discussed in this study shed light on the new attitude, marked by the ideas of post-Tridentine Catholic reformism and Enlightenment, which begins to spread among the new generations of 
Uniate hierarchs and scholars, educated in the Roman-Catholic learning institutions in the second half of the $18^{\text {th }}$ century. Following the shifts that occurred in Europe in terms of how the highly educated strata of society understood the functioning of the cosmos, with profound consequences in redefining reason, superstitions, and the idea of science, the Enlightenment's “crusade" against superstitions (CAMERON 2010:6, 310-315; PORTER 1999:197-236) - even in its milder form, specific to Central-European Enlightenment - even enters into the Romanian clerical environment. Certain types of knowledge and corpuses of information that had been established and perpetuated in time, which had the status of science in the pre-modern understanding of the concept, were now discredited and placed in the category of the irrational and superstition, according to the new order of knowledge (DARNTON 2000:191-195). The Păscălie also ends up belonging to this category, by juxtaposing to it the body of information and techniques comprised in divinatory and astrologic writings such as the Rojadnic, the Gromovnic, or the Trepetnic, although they remain popular and relevant mainly in the environment of common folk. The preface signed by Ioan Halmaghi tries to extricate the Păscălie from this category, as well as the calculation technique upon which it relies, pointing out its ecclesiastical origin and its function as disconnected from divination as well as its fundamental role in "the ordinances of the Eastern Church". Furthermore, considering that the work was especially dedicated to clergymen, the preface also seeks to draw attention to the wrong usage of the Păscălie as an instrument for divination. Nevertheless, as the various sources mentioned in this article indicate, throughout the $19^{\text {th }}$ century, the Păscălie not only continues to be associated with divination, but also asserts itself in popular culture as a generic ${ }^{19}$ term for any book used in such practices, whether we are talking about the Bible, the Moliftelnic, the Psaltery, or astrological literature. For instance, with respect to Negrea the Păscălitor, we learn from Grigore Sima a lui Ion's memorialist text, published in the Familia magazine, that

\begin{abstract}
"(...) in ten churches one did not celebrate Mass as much as in his house. In the morning, at noon, in the evening, and at midnight, just when the roosters are singing, prayers upon prayers. Healthy people and sick ones alike stand with their wax candles lit in their hands, some on their feet, while others on their knees, around the table, until he would read to them, full of piety: the Pillars, the chosen Psalms, and especially the Oratory of Saint Haralambios. Sometimes, he would even grapple with the Gospels from Great Lent. Most of the times, however, he would settle for the Păscălie, in which, besides planets and zodiac signs, there were also prayers specifically composed by the reader Samoilă, who had also heard them from another, who had lived for a longer time among the bedevilled" (1883:63-64).
\end{abstract}

\footnotetext{
${ }^{19}$ A simillar fate befell the Pravila, another term that in folk narratives about bibliomancy ends up designating any Church book used for such rituals. Originally, the Pravila was the code of laws developed over time by the church and used alongside the curse books also emitted by the church for the solving of various judiciary problems (MAZILU 2006:96). Probably because of the roles that clergymen served in the field of justice, maintained at least for matters of marriage and divorce up until the first few decades of the $19^{\text {th }}$ century (Mıнос 2012:10), the Pravila, which summed up the laws designated by God and which were constantly referred to, ended up being used to reference the books used, especially in the case of judicial-driven divination.
} 
Beyond the ironic tone of the narrative, which was specific to press articles and literary productions from the second half of the $19^{\text {th }}$ century - meant to ridicule the folk beliefs and practices that were considered superstitions by the increasing numbers of layman intellectuals - the fragment rendered above describes the Păscălie used by Negrea the Păscălitor as a Zodiac book, which also contains prayers. Its content reflects the mixture described in the case of Precista's Oratory - Paraclisul Precistii from Govora, which was characteristic of popular calendars or other printed materials. In the novella "Păscălierul" - "The Păscălier", inspired by a folk song and published in 1920 by Ion Agârbiceanu, the divinatory priest uses an old Moliftelnic (300). The short stories and lyrics meant to sanction the deviations of Romanian clerics that were published in the satirical and humorous magazine Calicul also mention the Păscălie when satirising priests that conduct bibliomancy. For this purpose, in issue no. 5 from May 1886, under the rubric Sus Marcule!, in which priests that had become famous for misconduct or other wrongdoings were ironically berated, the priest Popescu from Feisa is mentioned as one who "knew how to guess in the păscălie" (104). In issue no. 2 from February 1890 , in the satirical tale "Coana Gurădulce", a "new păscălie" is mentioned, given by a "warlock who had come from Rome" (43).

The fact that the Păscălie became one of the major references used with respect to the practice of bibliomancy in both church and popular discourse as well as among layman intellectuals throughout the $18^{\text {th }}$ and $19^{\text {th }}$ centuries, reflects several aspects regarding bibliomancy and its evolution. First of all, it can be stated that we are dealing with the use of a church book for divinatory purposes, an aspect underlined at length by researchers who have dealt with this phenomenon. Secondly, besides the fact that it generates an entire terminology used for circumscribing bibliomancy, the Păscălie itself, with its original function as a foundation for the Eastern calendar, is also comprised in divinatory writings and not only in church writings. The Păscălie and the method for calculating that it relies upon is one of the major elements that connect the Eastern tradition and an entire panoply of astrological and divinatory texts. The evolution of the Păscălie, at least the way it comes across from the texts belonging to Vicar Ioan Halmaghi, reflects its expulsion into the category of magic, divination, and superstition, and of writings and forms of knowledge specific to the Eastern tradition, by an ecclesiastical elite connected to the Western Christian tradition and to a world vision that was profoundly influenced by the ideas of Enlightenment and Catholic reformism. Naturally, the case of the Vicar also makes it evident how fascinating such writings and the forms of knowledge behind them could prove for Enlightenment-educated scholars. His case deserves more in depth study, especially since he does not enjoy any monographic study, unlike other hierarchs and scholars from his generation.

\section{REFERENCES CITED}

AgÂRBICEANU, Ion

1982 Păscălierul. Nuvele. Povestiri vol. I. Bucharest: Minerva.

1909 Părintele Vartolomei Bogdan [Father Vartolomei Bogdan]. Luceafărul 8(18). Sibiu. 
BĂLTEANU, Valeriu

2001 Dicționar de divinație populară românească [Dictionary of Romanian Popular Divination]. Bucharest: Paideia.

BIANU, Ioan - Hodoș, Nerva

1903 Bibliografia românească veche 1508-1830 [Romanian Early Bibliography] II. Bucharest: Romanian Academy Publishing House.

BiAnU, Ioan - Simionescu, Dan

1944 Bibliografia românească veche 1508-1830 [Romanian Early Bibliography] IV. Bucharest: Romanian Academy Publishing House.

Bogdan-DuiCĂ, George

1893 Petru Maior. Un studiu biographic [Petru Maior. A biography]. Cernăuți: Remuald Schally.

BuneA, Augustin

1902 Petru Pavel Aron și Dionisie Novacovici. Blaj.

BurTON RuSSEL, Jeffrey

1972 Witchcraft in the Middle Ages. Ithaca \& Londra, Cornell University Press.

CAMERon, Euan

2010 Enchanted Europe. Superstition, Reason, and Religion 1250-1750. Oxford University Press.

CANDREA, I.-Aurel

1931 Dicționarul Enciclopedic Ilustrat „Cartea Românească” [Illustrated Encyclopedic Dictionary]. Bucharest: Cartea Românească Publishing House.

Cartojan, Nicolae

1974 Cărțile populare în literatură românească [Popular Literature in Romanian Literature] II. Bucharest: The Encyclopaedic Publishing House.

1980 Istoria literaturii române vechi [History of Romanian Early Literature]. Bucharest: Minerva.

CoşBuc, George

1889 Pipăruș-Viteaz. Tribuna. Cluj-Napoca.

1909 Superstițiuni păgubitoare ale poporului nostru. Descântecul și leacurile băbești, duhurile necurate, vrăji și farmece, sărbători fără de rost [Our People's Damaging Superstitions. Chants and Old Wives' Remedies, Unclean Spirits, Spells and Charms, Pointless Holidays]. Bucharest.

CZÉGÉNYI, Dóra

2014 A román pap hiedelemköre a magyar népi kultúrában [The Beliefs of the Romanian Priest in Hungarian Popular Culture]. In CzÉGÉNYI, Dóra (ed.) $A$ mágikus erejü pap. Szerepek és helyzetek. Emberek és kontextusok 11, 331414. Societatea Muzeului Ardelean, Cluj-Napoca.

DARNTON, Robert

2000 Marele masacru al pisicii și alte episoade din istoria culturală a Franței [The Great Cat Massacre and Other Episodes in French Cultural History]. Iași: Polirom.

Diaconovich, C.

1904 Enciclopedia Română [Romanian Encyclopaedia]. Sibiu: W. Kraft. 
DoCAN, N.

1910 Despre elementele cronologice în documentele românești [Elements of Chronology in Romanian Documents]. Analele Academiei Române, $2^{\text {nd }}$ series, vol. 32. Bucharest.

DUDAŞ, Florian

1974-1975 Un catalog de documente din secolul al XVIII-lea identificat în părțile Zărandului [A collection of documents from eighteenth century discovered in Zărand region]. Sargetia 11-12.

Duicu, Serafim

1986 Pe urmele lui Samuil Micu-Clain [Research about Samuil Micu-Clain]. Bucharest.

Dumitran, Daniel

2007 Un timp al reformelor. Biserica Greco-Catolică din Transilvania sub conducerea episcopului Ioan Bob (1782-1830) [An Age of Reforms. The Greek-Catholic Church from Transylvania during the Episcopacy of Ioan Bob (1782-1830)]. Cluj-Napoca: Argonaut.

FURTUNĂ, Dumitru

1915 Preoțimea românească în secolul al XVIII-lea. Starea ei culturală și materială [Romanian Clergy from the Eighteenth Century]. Vălenii de Munte.

GASTER, Moses

1883 Literatura populară română [Romanian Popular Literature]. Bucharest.

GAVRILUȚĂ, Cristina

2008 Socioantropologia fenomenelor divinatorii [The Socialanthropology of Divination]. Iaşi: Institutul European.

HALMAGHI, Ioan

2016 „....non sine dolore observare debui...”. In Miskolczy, Ambrus (ed) Felvilágosodás és babonaság. Erdélyi néphiedelem-gyüjtés 1789-90-ben, 187-209. Budapest: L'Harmattan - Könyvpont.

IORGA, Nicolae

1902 Sate și preoți din Ardeal [Villagers and Priests from Transylvania]. Bucharest.

2012 Istoria Bisericii Românești și a Vieții Religioase a Românilor [History of the Romanian Church and of Romanian Religious Life] II, Saeculum I.O., Bucharest, (published in 1908-1909).

JARNIK, Ion Urban - BÂRSEANU, Andreiu

1895 Doine și strigături din Ardeal [Songs from Transylvania]. Brașov. JigA-ILIESCU, Laura

2003 Prezenţa şi sensul semnelor zodiacale în cultura tradiţională românească, între oficial şi popular, scriere şi oralitate [Zodiacal signs in Romanian traditional culture between official and popular]. Studii şi comunicări de etnologie, Tomul 17:23-31. Bucharest: Imago.

KeszeG, Vilmos

1996 A román pap és hiedelemköre a mezőségi folklórban [The Romanian Priest and His Beliefs in the Folklore of the Mezóség]. Ethnographia 107:335-369.

2007 Interpreting a Case of Vitiation. In Lūse, Agita - LÁzÁR, Imre (eds.) Cosmologies of Suffering: Post-communist Transformation, Sacral Communication, and Healing, 68-88. Cambridge Scholars Publishing. 
Komáromi, Tünde

1996 Rontásformák Aranyosszéken. A gyógyító román pap [Forms of bewitchment in the Aries Valley. The Romanian Orthodox priest as a healer]. Néprajzi Látóhatár V(1-2):87-98.

2010 Crossing Boundaries in Times of Personal Crisis: Seeking Help from Orthodox Clergy in Transylvania. In VAltchinova, Galia (ed.) Religion and Boundaries. Studies from the Balkans, Eastern Europe and Turkey, 155-166. Istanbul: The Isis Press.

Laurian, August, Treboniu - Massimu, J.C.

1876 Dictionariulu Limbei Romane [Romanian Language Dictionary] II. Bucharest. LUPAȘ, Ioan

1918 Istoria bisericească a românilor ardeleni [Church History of Transylvanian Romanians]. Sibiu.

1921 Mitropolitul Andrei Șaguna [Metropolitan Andrei Șaguna]. Sibiu.

MARIAN, Simion Florea

2012 Înmormântarea la români. Studiu etnografic [Romanian Funerals. An Ethnographic Study]. Bucharest: Saeculum I.O. (first issued in 1892).

MARICA, George, Em.,

1977 Studii de istoria și sociologia culturii române ardelene din secolul al XIX-lea [Historical and Sociological Studies on Romanian Culture from Nineteenth Century Transylvania] I. Cluj: Dacia.

Meteş, Ștefan

1929 Viața bisericească a Românilor din Țara Oltului. Note istorice [The Religious Life of Romanians from Olt County]. Transilvania 60(6):449-464. Sibiu.

Miron, Greta Monica

2004 Biserica greco-catolică din Transilvania. Cler şi enoriaşi (1697-1782) [The Greek-Catholic Church from Transylvania. Clergy and Parishioners (1697-1782)]. Cluj-Napoca: Cluj University Press.

Nelson Burnett, Amy

2000 Basel's Rural Pastors as Mediators of Confessional and Social Discipline. Central European History 33(1):67-85.

NiCOARĂ, Toader

1997 Transilvania la începuturile timpurilor modern (1680-1800). Societate rurală şi mentalități collective [Early Modern Transylvania. Rural Society and Mentalities]. Cluj-Napoca: Dacia.

OESTREICH, Gerhard

1982 The Structure of the Absolutist State. In: Neostoicism and the Early Modern State. Cambridge Unviersity Press.

OFrIM, Alexandru

2001 Cheia şi psaltirea. Imaginarul cărţii în cultura tradiţională românească [The Key and the Psalter. Books in the Romanian Traditional Culture]. Paralela 45, Piteşti.

PĂDURARU, Mircea

2014 The Book Opening Practice in the Context of Romanian Vernacular Religion. An Ethnological Reading of Some Theological Landmarks. Literature, Discourse and Multicultural Dialogue II. 247-254. 
PAMFILE, Tudor

1915 Mitologie Românească II. Comorile [Romanian Mythology I The Treasures]. Pócs, Éva Bucharest.

2004 Curse, Maleficium, Divination: Witchcraft on the Borderline of Religion and Magic. In DE BLÉCOURT, Willem - DAVIES, Owen (eds.) Witchcraft Continued. Popular Magic in Modern Europe, 174-190. Manchester University Press.

Popea, Nicolae

1879 Archiepiscopul și mitropolitul Andreiu baron de Șaguna [Archbishop and Metropolitan Andrei Șaguna]. Sibiu.

Pop-Curşeu, Ioan

1982 Povești Ardelenești [Transylvanian Stories]. Bucharest: Minerva.

2013 Magie și vrăjitorie în cultura română. Istorie, literatură, mentalități [Magic and Witchcraft in Romanian Culture. History, literature, mentalities]. Iaşi: Polirom-Cartea Românească.

PORTER, Roy

1999 Witchcraft and Magic in Enlightenment, Romantic and Liberal Thought. In AnKarloo, Bengt - Clark, Stuart (eds.) Witchcraft and Magic in Europe. The Eighteenth and Nineteenth Centuries, 191-283. Philadelphia: University of Pennsylvania.

REINHARDT, Wolfgang

1983 Zwang zur Konfessionalisierung? Prolegomena zu einer Theorie des konfessionallen Zeitalterst. Zeitschrift für historische Forschung 13:257-277.

ȘĂINEANU, Lazăr

1896 Dicționar Universal al Limbei Române [Universal Dictionary of Romanian Language]. Bucharest.

SCHILLING, Heinz

1988 Die Konfessionalisierung im Reich: Religiöser und gesellschaftlicher Wandel in Deutschland zwischen 1555 und 1620. Historische Zeitschrift 246:1-45.

Sima, Grigore

1883 Negrea Păscălitorul. Familia 19(6). Oradea.

ŞINCAI, Gheorghe

1964 Învăţătură firească spre surparea superstif̧iei norodului [A Natural Teaching Onto the Erosion of the Superstition of the Common Folk]. Bucharest: Scientific and Encyclopaedic Publishing House. (first issued in 1804-1808).

Stanca, Sebastian

1938 Viața și activitatea episcopului Vasile Moga (1774-1845) [The Life and Activity of Vasile Moga (1774-1845)]. Cluj.

ȘTREMPEL, Gabriel

1978-1992 Catalogul Manuscriselor Românești [Catalogue of Romanian Manuscripts]. Bucharest: Scientific and Encyclopaedic Publishing House.

TeOdorescu-KIRILEANU, G.

1904 Credinţi populare în cărţi bisericeşti [Popular beliefs regarding church books]. Şezătoarea nr. 6-7:81-87. 
Thomas, Keith

1973 Religion and the Decline of Magic. Studies in Popular Beliefs in Sixteenth and Seventeenth-Century England. London: Penguin Books.

WALKER, Alicia

2015 Magic in Medieval Byzantium. In J. Collins, David (ed.) The Cambridge History of Magic and Witchcraft in the West from Antiquity to the Present. Cambridge University Press.

WigZeLL, Faith

1998 Reading Russian Fortunes: Print Culture, Gender and Divination in Russia from 1765. Cambridge University Press.

1825 Lesicon românescu-latinescu-ungurescu-nemțescu [Romanian-Latin-HungarianGerman Lexicon] 1-2. Buda.

1886 Calicul. Humor și satiră, IV, No. 5, Mai, Sibiu.

1890 Calicul. Humor și satiră, X, No. 2, February, Sibiu.

1894 Rândunica, I, No. 1-3, Sibiu.

Valer Simion Cosma has a PhD in history from Babeş-Bolyai University, Cluj, Romania. He worked as an advanced researcher in the program Political Clientelism: a comprehensive frame for measuring electoral irregularities. His main research areas are: modernization of the rural world, the history and sociology of rural elites, the religiosity of peasants, political economy and nationalism. For two years (2015-2017), he has been assistant researcher in the "East-West" Research Group, HAS Research Centre for the Humanities, Institute of Ethnology, Budapest. Ha was founder of the Center for the Study of Modernity and the Rural World (2016), and of the projects Telciu Summer Conference (2012) and Telciu Summer School (2016). He edited three volumes of Telciu Summer Conferences ("Included and Excluded". The Identitary Issue During Modern and Contemporary Times, Cluj-Napoca, 2013; Buch-Wissen-Identität. Kulturwissenschaftliche Studien (RO-DE) (Book-Knowledge-Identity. Cultural Studies), eds. Valer Simion Cosma and Edit Szegedi, Cluj-Napoca, 2014; Religie-Cultură-Societate. Perspective interdisciplinare asupra vieții religioase/Religion-Culture-Society. Interdisciplinary perspectives on religious life ClujNapoca, 2015). He published several studies in collective volumes and scientific journals in Romania and abroad. E-mail: valer_cosma@yahoo.com 